\title{
Impact of bronchopulmonary dysplasia on pulmonary function during childhood: a systematic review
}

\author{
Janaina Cristina Scalco ${ }^{1}$, Rafaela Coelho Minsky², Francieli Camila Mucha ${ }^{3}$, Camila Isabel Santos Schivinski ${ }^{4}$
}

DOI: http://dx.doi.org/10.7322/jhgd.127685

\begin{abstract}
:
Introduction: Bronchopulmonary dysplasia (BPD) is a multifactorial chronic lung disease that contributes to disruption of pulmonary development. It may impair pulmonary function in early childhood and persist throughout school-age, adolescence, and into adulthood.
\end{abstract}

Objective: To analyze, through a systematic review, the impact of BPD on pulmonary function in early childhood.

Methods: Systematic searches were performed in three electronic databases (Medline, SciELO and PEDro). Two independent examiners analyzed the titles, abstracts and full texts, considering the following study inclusion criteria: studies of pulmonary function in up to 5-year-old children diagnosed with BPD in the neonatal period.

Results: Initially, 1789 articles were identified, and the final sample included 22 articles. It could be observed that children diagnosed with BPD in early childhood showed expiratory flow limitation and reduced functional residual capacity. However, pulmonary function in children with a history of BPD remains reduced when compared with healthy full-term children. Moreover, there are no positive responses in pulmonary function values with the use of bronchodilators.

Conclusion: Children with BPD show changes in pulmonary function, which may improve with growth, and most of them do not respond positively to bronchodilators.

Keywords: bronchopulmonary dysplasia, lung diseases, infant, respiratory function testing, child.

\section{INTRODUCTION}

Neonatal chronic lung disease, also known as bronchopulmonary dysplasia (BPD), is defined as the need for respiratory support with oxygen and/or mechanical ventilation in the first 28 days of life ${ }^{1-4}$. Children who developed the disease in the postnatal period may show abnormalities in pulmonary function ${ }^{5}$.

Currently, pulmonary function testing in early childhood, i.e., the time period ranging from 0 to 6 years including infants and preschoolers, can be performed by examinations, such as rapid chest compression, single breath occlusion, plethysmography and helium dilution ${ }^{6}$. Studies indicate that infants with BPD show compromised pulmonary function in the first years of life, with significant expiratory flow limitation, namely, forced expiratory volume in one second (FEV1), mean forced expiratory flow (FEF25-75\%), as well as reduced pulmonary compli- ance, increased pulmonary resistance, higher respiratory rate, reduced functional residual capacity (FRC) and residual volume ${ }^{7-24}$

These results are characteristics of ventilatory and functional changes, the knowledge of which may provide a better understanding of the disease and, consequently, improve treatment and preventive strategies to manage the disease. Therefore, this study aimed to analyze the impact of bronchopulmonary dysplasia on the pulmonary function of infants and preschool children between 0 and 4 years of age.

\section{METHODS}

\section{Search Strategy}

The literature review strategy included electronic searching using three bibliographic online databases: SciELO (Scientific Electronic Library Online), PEDro (Physio-

\footnotetext{
1 M.A., Professor of the Department of Physiotherapy at the State University of Santa Catarina, Florianopolis/SC/Brazil.

2. Physiotherapist, Master's Degree in Physiotherapy from the State University of Santa Catarina, Florianopolis/SC/Brazil.

3. Physiotherapist, Graduate Student in the Graduate Program for Physiotherapy at the State University of Santa Catarina, Florianopolis /SC/Brazil.

4. Ph.D., Full Professor of the Department of Physiotherapy at State University of Santa Catarina, Florianopolis/SC/Brazil.

Corresponding Author: Camila I. S. Schivinski - E-mail: cacaiss@yahoo.com.br
} 
therapy Evidence Data base) and Medline (Medical Literature Analysis and Retrieval System Online via Ovid. The publications were selected until the date of online searching, i.e., September 2016, regardless of the language.

The authors developed a search strategy for Medline (via OVID web) and PEDro, which are shown in (Figure 1), due to the absence of this type of publication on the topic. The following keywords were used for the SciELO database: displasia broncopulmonar, bronchopulmonary dysplasia.

\section{Selection Strategy}

The articles were screened by 2 examiners, who independently analyzed the results of the online search for potentially eligible articles. The publications which met all previously established inclusion criteria were selected, and doubtful cases were discussed. First, the reviewers read the titles, followed by an analysis of the abstracts.
The studies that proved to be eligible were reviewed in full, in agreement with the recommendations of the Main Items for Reporting Systematic Reviews and Meta-analysis (PRISMA) ${ }^{25,26}$ (Figure 2).

\section{Analysis of data}

Inclusion criteria were: clinical trials that assessed pulmonary function of infants and preschool children aged 0-4 years with a diagnosis of BPD in the neonatal period. The diagnosis of BPD was defined as the need for supplemental oxygen above $21 \%$ during 28 days or more.24 Studies that were not available through the Program Manager Bibliographic Commuting (Comut), the newspaper's website or Ovid database, were not used for analysis.newspaper's website or Ovid database, were not used for analysis.

Figure 1: search strategy

\author{
Medline (ovid web) \\ 1. Randomized controlled trials as topic/ \\ 2. Randomized controlled trial/ \\ 3. Random allocation/ \\ 4. Double blind METHODS/ \\ 5. Single blind method/ \\ 6. Clinical trial/ \\ 7. Exp clinical trials as topic/ \\ 8. (Clinic* adj trial $\left.{ }^{*} 1\right) \cdot \mathrm{Mp}$. \\ 9. ((Singl ${ }^{*}$ or doubl* or tripl* $\left.{ }^{\star}\right)$ adj (blind ${ }^{*} 3$ or mask $\left.\left.{ }^{*} 3\right)\right)$. Mp. \\ 10. Placebos/ \\ 11. Placebo*.Mp. \\ 12. Randomly allocated.Mp. \\ 13. (Allocated adj2 random).Mp. \\ 14. 1 Or 14 \\ 15. Bronchopulmonary dysplasia/ \\ 16. Pulmonary dysplasia \\ 17. Infant, premature, diseases/ \\ 18. Respiratory distress syndrome newborn/ \\ 19. Respiratory system abnormalities/ \\ 20. Pulmonary fibrosis/ \\ 21. Or/17-22 \\ 22. Lung volume measurements/ \\ 23. Respiratory function tests/ \\ 24. Pulmonary function test ${ }^{*}$.Mp. \\ 25. Exercise test/ \\ 26. Exercise tolerance/ \\ 27. Spirometry/ \\ 28. Lung capacity \\ 29. Vital capacity/ \\ 30. Airway resistance/
}
31. Or/24-32
32. Infant, newborn/
33. Infant, low birth weight/
34. Infant, premature/
35. Neonate.mp.
36. Child*.mp.
37. Pediatr*.mp.
38. Adolescent*.mp.
39. School age.mp.
40. Child, Preschool/
41. or/34-42
42. 16 and 23 and 33 and 43

PEDro

Strategy 1

Field Title/abstract: Bronchopulmonary dysplasia

Field Therapy: respiratory therapy

Field METHODS: clinical trial

Field Problem: No appropriate

\section{Strategy 2}

Field Title/abstract: Bronchopulmonary dysplasia

Field Therapy: respiratory therapy

Field METHODS: clinical trial

Field Problem: impaired ventilation

\section{SciELO}

Displasia broncopumonar or bronchopulmonary dysplasia [all indexes]

\section{RESULTS}

A total of 1789 articles were identified, 61 titles of which were selected for analysis of their respective abstracts. Next, 33 articles were shortlisted for full review, and 11 were excluded because they did not meet the inclusion criteria. The final sample consisted of 22 articles as shown in the flowchart (figure 2).

Of the 22 articles included (table 1), 12 assessed children with a history of BPD at different moments (longitudinal) $)^{7-16,27,28}$ and the maximum follow-up was the interval between the neonatal hospital stay and five years of life. The remaining ten reviewed studies performed pulmonary function testing in one single moment (transversal). ${ }^{17-22,29-32}$ 
Figure 2: Flowchart showing selection of articles for review (adapted from Moher et al. 2009)
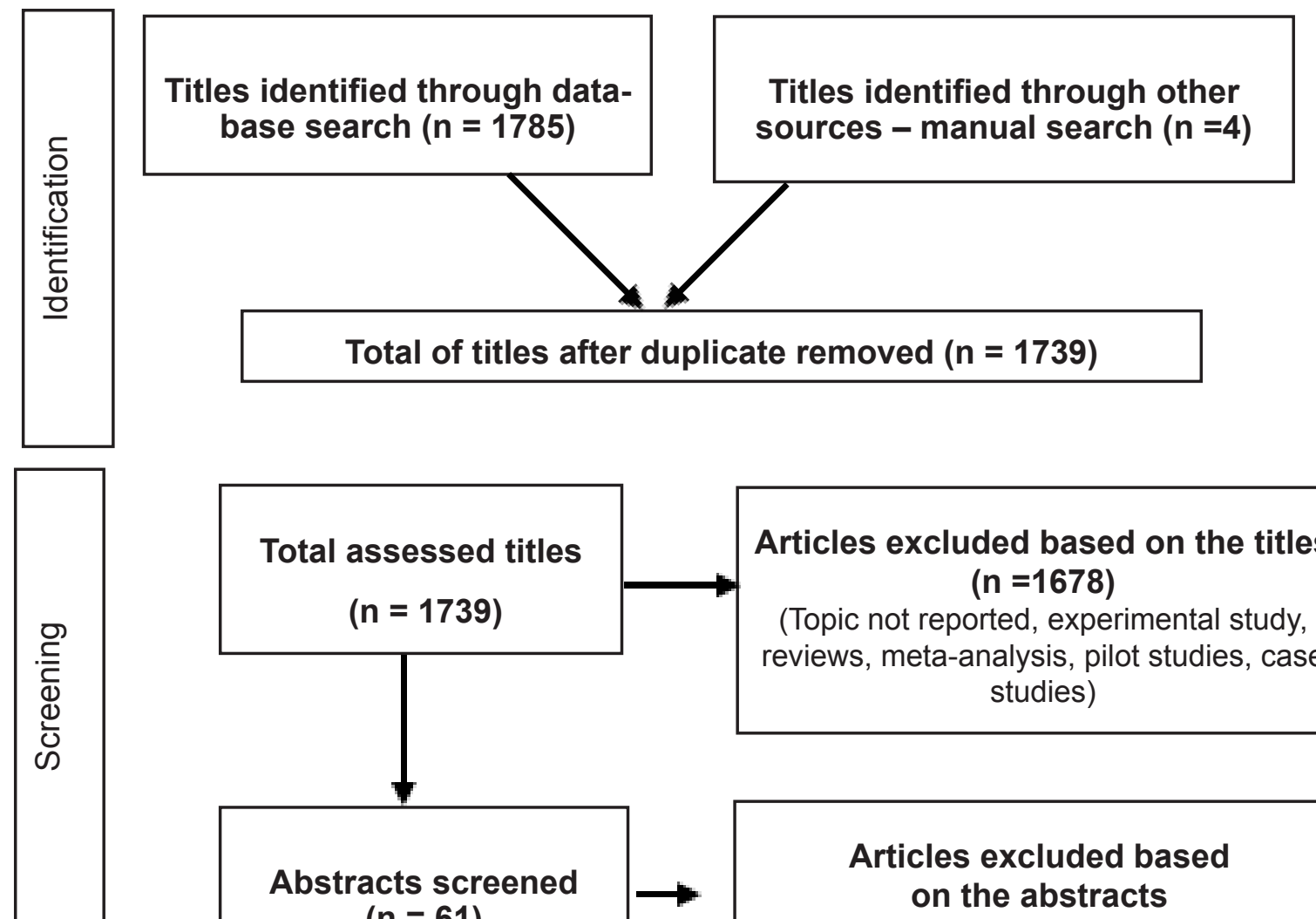

Articles excluded based on the titles ( $n=1678)$

(Topic not reported, experimental study, reviews, meta-analysis, pilot studies, case studies)

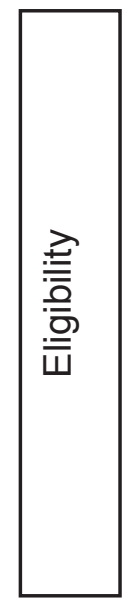

Abstracts screened $(n=61)$

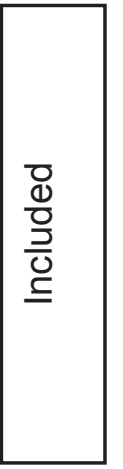

Articles excluded based on the abstracts

$$
(n=28)
$$

Unavailable (5)

Experimental study (4)

Topics not reported (4)

Other type of study (6)

Other type of disease (9)

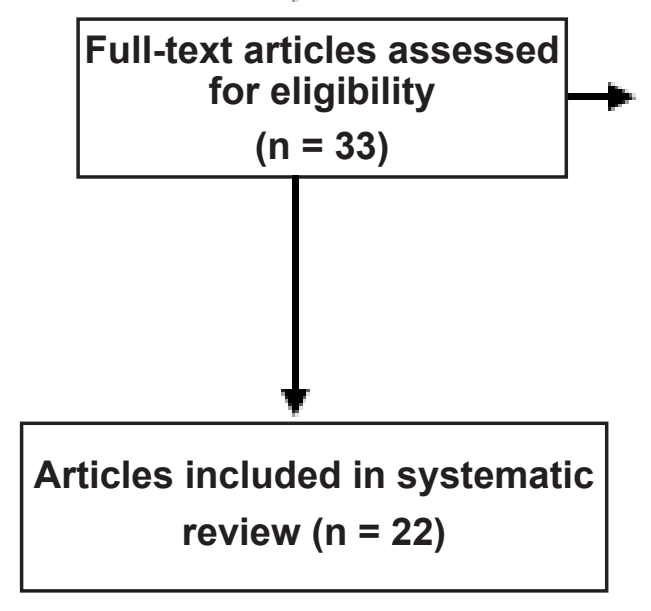


Table 1: Summary of articles selected for systematic review

Author, Year

Tepper et al., 1986

Hjalmarson et al., 2005

Farstad et al.,1995

Schmalisch et al., 2005

Filbrun et al., 2011

Baraldi et al., 1997

Schmalisch, 2012.

Boeck et al.,1998

Pérez et al., 1999

Robin et al., 2004

Thunqvist et al., 2014

May et al., 2011

Balinotti et al., 2010

Mahut et al., 2007

Mallory et al., 1991

Vural et al., 1996

Khoulood et al., 2010

Vrijlandt et al., 2007

Greenough et al., 2005

Kavvadia et al., 1998

Wei et al., 2013

Fouzas et al., 2013

\section{Results}

Compared to CG, BPDG had lower FRC up to 10.5 months of PCA; BPDG showed decreased corrected and absolute expiratory flows compared to CG. The linear regression slope of the VMAXFRC $x$ length was lower in BPDG, indicating low AWs growth.

Severe BPD showed reduced FRC, less efficient gas mixture and higher specific conductance, compared with CG, mild and moderate BPD.

RSR was higher in BPDG than in CG with 50 weeks of CA, but decreased with 120 weeks. Analysis of the VMAXFRC showed that $80 \%$ of the children with BPD and $58 \%$ of CG had severe periphera obstruction with 50 weeks; no controls with 120 weeks $(p<0.05)$ and 38\% BPDG with severe obstruction.

Differences between children with BPD and CG were found during tidal breathing of 0.45 vs 0.65 ; RR: 55.4 vs 39.2 .

In the first evaluation, FEV0.5, FEV75, FEV 25-75 showed significant reduced values. In the re-evaluation, mean lung volume and flow remained close to the initial values, below the predicted, indicating lack of pulmonary growth. Children with above-average growth showed improved FVC, FEV0.5, TLC, and RV/TLC.

Severe changes in the mechanical properties of the RSR lung were found during the acute phase of BPD. The progressive improvement occurred from 3 months. At 24 months of age, RSR reached the normal range.

There was no significant difference between the groups regarding RR, TRR and AWs, or blood gas levels. CV, EV, pulmonary compliance and FRC were lower in children with BPD compared to CG. However, these differences became non-significant after normalization of body weight.

There was no significant decrease in lung resistance after inhalation of salbutamol or ipratropium bromide in patients with BPD.

Mean values for compliance and RSR were within normal range; mean value for peak expiratory flow time was below normal, indicating airway obstruction.

BPDG showed lower FEV0.5, FEV75, FEV25-75; and FRC, RV, and RV/TLC higher than CG. In BPDG, 17 patients underwent a bronchodilator testing and only 6 showed bronchodilator response.

Only FRC values and RS compliance at 18 months were not below the normal values; all other lung function measurements were significantly below normative values. During follow-up at 6 and 18 months, NB with respiratory symptoms had lower values of maximum and mean forced expiratory peak, and RS compliance value compared to individuals without symptoms.

NB who developed moderate/severe BPD had lower FRC values and compliance over the entire 28 day period, compared to those who did not develop BPD. The rate of improvement in FRC and compliance over the first 28 days was higher in NB with moderate/severe BPD.

Individuals with BPD had a significant decrease in lung diffusion compared to CG subjects. Pulmonary capacity was significantly lower for individuals with BPD compared to CG.

Most children showed low VmaxFRC values, suggesting an obstructive pattern. Strong correlations were observed between FRC measurements and oxygen exposure.

During the first 6 months of age in both groups, FVC was significantly lower in BPDG, compared to normal value. At 24 and 36 months of age, mean FVC was even lower in Group B than in Group $A$, but the difference was not significant.

Significant relationships were found between thoracic distension and duration of positive inspiratory pressure $(P<0.05, r=0.43)$, duration of positive expiratory pressure $(P<0.05, r=0.45)$, total time of oxygen therapy; between total lung resistance and duration of mechanical ventilation with high frequency $(P<0.05: r=0.52)$; between hypoxemia and time of oxygen therapy with $\mathrm{FiO} 2>-60 \%(P<0.05 ; r=0.54)$.

Children with BPD had low expiratory airflow at 6, 12, and 24 months, respectively, with no significant improvement over time. FRC has increased significantly over time.

The resonance frequency was higher in BPD compared to non-BPD (mean of 26.8 vs 22.7, P $<0.001)$ and lower mean reactance X4-24 (hPa.s / I) (- 3.0 vs. $-1.9, \mathrm{P}<005)$.

Children with BPD showed significantly lower pulmonary values, compared with non-BPD children.

FRC at 14 and 28 days were lower in group $A$ than in group $C(P<0.01)$. Group $B$ showed lower difference $(P<0.05)$ at 28 days, when compared to group $C$.

In moderate and severe BPD groups, RR was higher than in the non- BPD group. In the BPD group, FRC was higher than the moderate and severe groups.

Capnography waveforms in phase II (SII) and III (SIII) were more pronounced in children with BPD compared to healthy preterm and full-term infants.

Legend: CG: control group; BPDG: group with bronchopulmonary dysplasia; FRC: functional residual capacity; PCA: post- conceptional age; AWs: airways; RSR: respiratory system resistance; CA: corrected age; RR: respiratory rate; FEV0.5: forced expiratory volume at half second; FEV75: forced expiratory volume at $75 \%$ of curve of forced vital capacity; FEV25-75: forced expiratory volume between 25 and $75 \%$ curve of forced vital capacity; FVC: forced vital capacity; TLG: total lung capacity; RV: residual volume; RV/TLC: residual volume and total lung capacity ratio; TRR: total respiratory resistance; CV: current volume; EV: expiratory volume; RS: respiratory system; NB: new-born; FiO2: fraction of inspired oxygen. 


\section{DISCUSSION}

Notably, maintaining the integrity of the respiratory system in the first two years of life is essential and will determine the improvement of gas exchange and respiratory reserve after infancy ${ }^{33}$ as this is the period of greatest alveolar growth ${ }^{34}$. In this review, the studies suggest that respiratory symptoms and pulmonary function seem to improve in early childhood ${ }^{7,8,10,12,27}$ with the growth and development of the child with a history of BPD. Farstad et al. ${ }^{12}$ found that, at 50 weeks of corrected age (CA), $80 \%$ of the children with BPD in their study sample had severe peripheral obstruction, compared to $58 \%$ of preterm infants without BPD. In the reevaluation period (120 weeks of CA), only $38 \%$ of the children with BPD presented with severe obstruction versus no preterm children. According to Sanchez et al. ${ }^{35}$ the progressive improvement of capacity and flow-volume curves in this population is proportional to the increase in weight and length of infants. On the other hand, Hjalmarson et al. ${ }^{13}$ observed that the pulmonary function in infants using bronchodilators remains reduced even after normalization of weight, compared to healthy infants. However, these alterations may not be significant considering the normal values of pulmonary function parameters ${ }^{12,17}$. In this context, some authors ${ }^{7,8,10}$ point out that improved pulmonary function during infancy is more evident in children with moderate/severe BPD, compared to those with mild BPD, or in preterm infants without $\mathrm{BPD}^{28}$.

It is well-established that some complications caused by BPD in early childhood may favor high rates of respiratory infections, recurrent wheezing and hospital readmissions ${ }^{12,28,33,34,36}$. According to a study conducted by Tepper et al. ${ }^{14} 55 \%$ of infants with BPD required prehospitalization during the first year of life due to diseases of the lower respiratory tract. The incidence of respiratory morbidity and prehospitalization has been lower in healthy fullterm infants ${ }^{28}$, as well as in preterm infants who developed respiratory distress syndrome ${ }^{12}$ when compared to infants with bronchopulmonary dysplasia . However, Mahut et al. ${ }^{29}$ observed that there is no difference in pulmonary function among BPD infants with frequent symptoms and those with fewer or no symptoms, and all of them showed reduced FRC. These results suggest that pulmonary function as well as other factors may be involved in the high susceptibility to respiratory infections in this population.

Another topic identified in the current review is the response of BPD children to bronchodilators. The selected studies demonstrate no reduction in inspiratory and expiratory resistance after the use of bronchodilators in most children with a history of BPD.
Children who respond to these medications show greater abnormalities in pulmonary function parameters than non-responders ${ }^{22,32}$. According to Fakhoury et al..$^{23}$ up to 3 years of age, only 20 to $30 \%$ of children with moderate to severe BPD show bronchodilator response. Therefore, this drug should not be indicated for all patients with $\mathrm{BPD}$, but only for responders or patients show worsening in wheezing during acute respiratory exacerbation ${ }^{22,32}$.

Current articles and reviews have shown limited pulmonary function, functional capacity and quality of life of schoolchildren ${ }^{37}$ and adults ${ }^{38}$ with BPD. However, the impact of BPD on infants and preschool children has not been often discussed. This review was able to collect results of current studies about the disease in this age group. A limitation of this review is the lack of classification of the methodological quality, by means of valid instruments.

In summary, children with a history of BPD usually show alterations in pulmonary function in the first three years of life, which seems to improve with growth and become non-significant after body weight adequacy. However, when comparing BPD children with full-term children, this limitation can still be observed. Also, most BPD children do not show positive response in pulmonary function after the use of inhaled bronchodilator. But, responders have compromised pulmonary function.

Admittedly, there is a gradual improvement of pulmonary function in the first years of life. Therefore, public health professionals involved in the care of this population should consider the importance of nutritional aspects and prevention of respiratory infections in this period, in order to allow conditions for adequate pulmonary growth and development. This may attenuate alterations in pulmonary function due to neonatal injury. Furthermore, early identification of possible impairment of pulmonary function may help pediatricians and/or pulmonologists to prevent disease complications by means of strategies, e.g., to encourage children to keep regular physical activities as soon as possible, and to refer patients for physical therapy as a preventive measure or during acute respiratory events.

\section{CONCLUSION}

It could be observed that children diagnosed with BPD during the neonatal period showed expiratory flow limitation and reduced FRC when assessed in early childhood, compared to healthy full-term and preterm children. Most children show improved values of pulmonary function with growth and normalization of weight.

\section{REFERENCES}

1. Gupta S, Sinhá SK, Donn SM. Ventilatory management and bronchopulmonary dysplasia in preterm infants. Semin Fetal Neonatal Med. 2009;14(6):367-73. DOI: http://dx.doi.org/10.1016/j.siny.2009.08.011

2. Gonzaga AD, Figueira BBD, Sousa JMA, Carvalho WB. Tempo de ventilação mecânica e desenvolvimento de displasia broncopulmonar. Rev Ass Med Bras. 2007;53(1):64-7. DOI: http://dx.doi.org/10.1590/S0104-42302007000100022

3. Isayama T, Iwami H, McDonald S, Beyene J. Association of noninvasive ventilation strategies with mortality and bronchopulmonary dysplasia among preterm infants: a systematic review and meta-analysis. JAMA. 2016;316(6):611-24. DOI: http://dx.doi.org/10.1001/jama.2016.10708 
4. Lima MRO, Andrade MA, Araújo APG, Figueroa JN, Andrade LB. Influência de fatores maternos e neonatais no desenvolvimento da displasia broncopulmonar. Rev Assoc Med Bras. 2011;57(4):398-403. DOI: http://dx.doi. org/10.1590/S0104-42302011000400012

5. Coalson JJ. Pathology of new bronchopulmonary dysplasia. SeminNeonatol. 2003; 8(1):73-81.

6. Pérez Tarazona S, Rueda Esteban S, Alfonso Diego J, Barrio Gómez de Agüero MI, Callejón Callejón A, Cortell Aznar I, et al. Guidelines for the follow up of patients with bronchopulmonary dysplasia. An Pediatr (Barc). 2016;84(1):61e1-9. DOI: http://dx.doi.org/10.1016/j.anpedi.2015.04.020

7. Mallory GB Jr, Chaney H, Mutich RL, Motoyama EK. Longitudinal changes in lung function during the first three years of premature infants with moderate to severe bronchopulmonary dysplasia. Pediatr Pulm.1991;11(1):8-14.

8. Baraldi E, Filippone M, Trevisanuto D, Zanardo V, Zacchello F. Pulmonary function until two years of life in infants with bronchopulmonary dysplasia. Am Respir Crit Care Med. 1997;155(1):149-55. DOI: http://dx.doi.org/10.1164/ ajrccm.155.1.9001304

9. Fakhoury KF, Sellers C, Smith E O’Brian, Rama JA, Fan LL. Serial Measurements of Lung Function in a Cohort of Young Children WithBronchopulmonary Dysplasia. Pediatrics. 2010;125(6).

10. Filbrun AG, Popova AP, Linn MJ, McIntosh NA, Hershenson MB. Longitudinal measures of lung function in infants with bronchopulmonary dysplasia. Pediatr Pulmonol. 2011;46(4):369-75. DOI: http://dx.doi.org/10.1002/ppul.21378

11. Thunqvist $P$, Gustafsson P, Norman M, Wickman M, Hallberg J. Lung function at 6 and 18 months after preterm birth in relation to severity of bronchopulmonary dysplasia. Pediatr Pulmonol. 2015;50(10):978-86. DOI: http://dx.doi. org/10.1002/ppul.23090

12. Farstad T, Brockmeier F, Bratlid D. Cardiopulmonary function in premature infants with bronchopulmonary dysplasia 2-year follow up. Eur J Pediatr. 1995;154(10):853-8. DOI: http://dx.doi.org/10.1007/BF01959797

13. Hjalmarson O, Sandberg KL. Lung function at term reflects severity of bronchopulmonary dysplasia. J Pediatr. 2005 Jan;146(1):86-90. DOI: http://dx.doi.org/10.1016/j.jpeds.2004.08.044

14. Tepper RS, Morgan WJ, Cota K, Taussig LM. Expiratory flow limitation in infants with bronchopulmonary dysplasia. J Pediatr. 1986;109(6):1040-6. DOI: http://dx.doi.org/10.1016/S0022-3476(86)80296-7

15. Kavvadia V, Greenough A, Dimitriou G, Itakura Y. Lung volume measurements in infants with and without chronic lung disease. Eur J Pediatr. 1998;157(4):336-9. DOI: http://dx.doi.org/10.1007/s004310050823

16. Vural M, Kremp O, Cambier F, Krim G, Kilani L, Leke L, et al. Evolution of the result of respiratory function studies in children with bronchopulmonary dysplasia. Arch Pediatr. 1996;3(12):1229-38.

17. Schmalisch G, Wilitzki S, Wauer RR. Differences in tidal breathing between infants with chronic lung diseases and healthy controls. BMC Pediatr. 2005;5:36. DOI: http://dx.doi.org/10.1186/1471-2431-5-36

18. Greenough A, Broughton S. Chronic manifestations of respiratory syncytial virus infection in premature infants. Pediat Infect Dis J. 2005;24(11 Suppl): S184-7.

19. Balinotti JE, Chakr VC, Tiller C, Kimmel R, Coates C, Kisling J, et al. Growth of lung parenchyma in infants and toddlers with chronic lung disease of infancy. Am J Respir Crit Care Med. 2010;181(10):1093-7. DOI: http://dx.doi. org/10.1164/rccm.200908-11900C

20. Vrijlandt EJ, Gerritsen J, Boezen HM, Grevink RG, Duiverman EJ. Lung function and exercise capacity in young adults born prematurely. Am J Resp Crit Care Med. 2006;173(8):890-6. DOI: http://dx.doi.org/10.1164/rccm.200507$1140 \mathrm{OC}$

21. Wei MC, Yu JL, Liu XH, Qi LF. Characteristics of lung function in preterm infants with varying degrees of bronchopulmonary dysplasia. Zhonghua Yi Xue Za Zhi. 2013;93(22):1716-20.

22. Robin B, Kim YJ, Huth J, Klocksieben J, Torres M, Tepper RS, et al. Pulmonary function in bronchopulmonary dysplasia. Pediatr Pulmonol. 2004;37(3):236-42. DOI: http://dx.doi.org/10.1002/ppul.10424

23. Fakhoury KF, Sellers C, Smith EO, Rama JA, Fan LL. Serial measurements of lung function in a cohort of young children with bronchopulmonary dysplasia. Pediatrics. 2010;125(6):e1441-7. DOI: http://dx.doi.org/10.1542/peds.20090668

24. Jobe AH, Bancalari E. Bronchopulmonary dysplasia. Am J Respir Crit Care Med. 2001;163(7):1723-9. DOI: http:// dx.doi.org/10.1164/ajrccm.163.7.2011060

25. Moher D, Cook DJ, Eastwood S, Olkin I, Rennie D, Stroup DF. Improving the quality of reporting of meta-analsis of randomised controlled trials: the QUOROM statement. Quality of Reporting of Meta-analyses. Lancet. 1999;354(9193):1896-900.

26. The Cochrane Collaboration. Glossary of terms in The Cochrane Collaboration [Internet]. Version 4.2.5. London: Cochrane Collaboration; 2005.

27. Schmalisch G, Wilitzki S, Roehr CC, Proquitté H, Bührer C. Development of lung function in very low birth weight infants with or without bronchopulmonary dysplasia: longitudinal assessment during the first 15 months of corrected age. BMC Pediatr. 2012;12:37. DOI: http://dx.doi.org/10.1186/1471-2431-12-37

28. May C, Kennedy C, Milner AD, Rafferty GF, Peacock JL, Greenough A. Lung function abnormalities in infants developing bronchopulmonary dysplasia. Arch Dis Child. 2011;96(11): 1014-9. DOI: http://dx.doi.org/10.1136/ adc.2011.212332

29. Mahut B, De Blic J, Emond S, Benoist MR, Jarreau PH, Lacaze-Masmonteil T, et al. Chest computed tomogra- 
phy findings in bronchopulmonary dysplasia and correlation with lung function. Arch Dis Child Fetal Neonatal Ed. 2007;92(6):F459-64. DOI: http://dx.doi.org/10.1136/adc.2006.111765

30. Perez CA, Bui KC, Bustorff-Silva J, Atkinson JB. Comparison of intratracheal pulmonary ventilation and hybrid intratracheal pulmonar ventilation with conventional mechanical ventilation in a rabbit model of acute respiratory distress syndrome by saline lavage. Crit Care Med. 2000;28(3):774-81.

31. Fouzas S, Häcki C, Latzin P, Proietti E, Schulzke S, Frey U, et al. Volumetric capnography in infants with bronchopulmonary dysplasia. J Pediatr. 2014;164(2):283-8.e1-3. DOI: http://dx.doi.org/10.1016/j.jpeds.2013.09.034

32. Boeck K, Smith J, Van Lierde S, Devlieger H. Response to bronchodilators in clinically stable 1-year-old patients with bronchopulmonary dysplasia. Eur J Pediatr. 1998;157(1):75-9. DOI: http://dx.doi.org/10.1007/s004310050771

33. Chien YH, Tsao PN, Chou HC, Tang JR, Tsou KI. Rehospitalization of extremely-lowbirth-weight infants in first 2 years of life. Ear Hum Dev. 2002;66(1):33-40. http://dx.doi.org/10.1016/S0378-3782(01)00233-X

34. Doyle LW, Ford G, Davis N. Health and hospitalistions after discharge in extremely low birth weight infants. Semin Neonat. 2003;8(2):137-45. DOI: http://dx.doi.org/10.1016/S1084-2756(02)00221-X

35. Sanchez-Solis M, Perez-Fernandez V, Bosch-Gimenez V, Quesada JJ, Garcia-Marcos L. Lung function gain in preterm infants with and without bronchopulmonary dysplasia. Pediatr Pulmonol. 2016;51(9):936-42. DOI: http:// dx.doi.org/10.1002/ppul.23393

36. Ronkainen E, Kaukola T, Marttila R, Hallman M, Dunder T. School-age children enjoyed good respiratory health and fewer allergies despite having lung disease after preterm birth. Acta Paediatr. 2016;105(11):1298-1304. DOI: http:// dx.doi.org/10.1111/apa.13526

37. Scalco JC, Medeiros DL, Schivinski CIS. Capacidade de exercício e função pulmonar de escolares com história de displasia broncopulmonar: revisão sistemática. Medicina (Ribeirão Preto). 2015;48(5):501-11.

38. Gough A, Linden M, Spence D, Patterson CC, Halliday HL, McGarvey LP. Impaired lung function and health status in adult survivors of bronchopulmonary dysplasia. Eur Resp J. 2014;43(3):808-16. DOI: http://dx.doi. org/10.1183/09031936.00039513

This article is distributed under the terms of the Creative Commons Attribution 4.0 International License (http://creativecommons.org/licenses/by/4.0/), which permits unrestricted use, distribution, and reproduction in any medium, provided you give appropriate credit to the original author(s) and the source, provide a link to the Creative Commons license, and indicate if changes were made. The Creative Commons Public Domain Dedication waiver (http://creativecommons.org/publicdomain/zero/1.0/) applies to the data made available in this article, unless otherwise stated. 


\section{Resumo}

Introdução: A displasia broncopulmonar (DBP) é uma doença pulmonar crônica multifatorial que interrompe o desenvolvimento pulmonar, podendo repercutir em comprometimento da função pulmonar na primeira infância, que pode perdurar durante a idade escolar, adolescência, até a idade adulta.

Objetivo: Analisar, através de uma revisão sistemática, as repercussões da DBP na função pulmonar de crianças na primeira infância.

Método: Foram realizadas buscas sistematizadas em três bases de dados eletrônicas (Medline, SciELO e PEDro). Dois examinadores independentes analisaram sistematicamente os títulos, resumos e textos na íntegra, considerando os seguintes critérios de inclusão: estudos que avaliaram a função pulmonar de crianças com até 5 anos de idade que apresentaram diagnóstico de DBP no período neonatal.

Resultados: Inicialmente foram identificados 1789 artigos, sendo que a amostra final foi composta de 22 artigos. Evidenciou-se que crianças com DBP apresentam na primeira infância limitação dos fluxos expiratórios e redução da capacidade residual funcional. Estas alterações podem ser normalizadas ou minimizadas com o crescimento e adequação de peso, porém, a função pulmonar das crianças com história de DBP continua reduzida em comparação a crianças hígidas nascidas a termo. Ainda, a maioria delas não apresenta respostas positivas nos valores de função pulmonar com o uso de broncodilatadores.

Conclusão: Crianças com DBP apresentam alterações na função pulmonar, podendo melhorar com o crescimento, sendo que a maioria não responde positivamente ao broncodilatador.

Palavras-chave: displasia broncopulmonar, doenças pulmonares, lactente, testes de função respiratória, criança. 